\title{
ANALISIS TINGKAT KETEPATAN KONSEP BUKU TEKS BIOLOGI BILINGUAL
}

\author{
Aan Pathiyah 1) \\ ${ }^{1}$ Program Studi Pendidikan Guru Sekolah Dasar, FKIP Universitas Islam Al-Ihya Kuningan \\ Email : aan_pathiyah@yahoo.com
}
APA Citation: Pathiyah, A. (2019). Analisis Tingkat Ketepatan Konsep Buku Teks Biologi Bilingual. Quagga: Jurnal Pendidikan dan Biologi, 11(2), 59-64. doi: 10.25134/quagga.v11i2.1839.

Received: 24-06-2019

Accepted: 25-07-2019

Published: 26-07-2019

\begin{abstract}
Abstrak: Penelitian ini bertujuan untuk mengetahui Analisis Tingkat Ketepatan Konsep Buku Teks Biologi Bilingual SMP Kelas IX menggunakan model penyajian motif. Metode yang digunakan dalam penelitian adalah pendekatan kualitatif studi eksploratori. Penelitian menghasilkan konsep memadai yang cukup dominan sebesar $91 \%$ dan $2 \%$ konsep yang tidak dituntut dalam indikator. Namun masih terdapat kekurangan dalam penyajiannya, yaitu kurangnya atribut kritis pada konsep sebesar 7\% meskipun tidak sampai menimbulkan miskonsepsi. Artinya konsep-konsep yang ditemukan di dalam buku teks dikatakan sangat baik. Kesimpulan yang diperoleh buku teks tersebut dapat digunakan dalam proses pembelajaran sebagai bahan ajar dan berfungsi sebagai buku teks bilingual yang tepat.
\end{abstract}

Kata kunci : Ketepatan konsep, buku teks, penyajian motif

Abstract: This study aims to find out the Appropriateness of the Textbook Concept Concept of Bilingual Biology of SMP Class IX using a model of motive presentation. The method used in this research is the qualitative approach of exploratory study. The research yields quite a dominant enough concept of $91 \%$ and $2 \%$ concepts not required in the indicator. But there is still a lack in presentation, namely the lack of critical attributes on the concept of $7 \%$ although not to cause misconception. This means that the concepts found in the textbook are said to be very good. The conclusions obtained by the textbook can be used in the learning process as teaching material and serve as a proper bilingual textbook.

Keywords: Accuracy of concepts, textbooks, presentation of motives

\section{PENDAHULUAN}

Sebagai buku sumber, buku teks berperan memberi petunjuk kegiatan, memberi motivasi dan pertanyaan-pertanyaan, menghubungkan materi pelajaran dengan pengalaman kehidupan sehari-hari. Buku teks yang baik perlu memiliki kebenaran isi, penggunaan bahasa yang jelas, serta penyajian yang sistematis. Kelayakan ini ditentukan oleh penilaian yang dilakukan Badan Standar Nasional Pendidikan (BSNP) dan ditetapkan berdasarkan Peraturan Menteri Pendidikan Nasional (Permendiknas). Buku teks yang dapat digunakan sebagai penunjang bahan ajar adalah yang isinya layak untuk digunakan dalam proses pembelajaran dan ditetapkan sebagai buku teks pelajaran berdasarkan Peraturan Menteri Pendidikan Nasional.

Kriteria yang digunakan untuk mencapai kondisi diatas merujuk pada ketepatan konsep yang telah dirumuskan dalam pedagogi materi subjek menggunakan penyajian motif. Dalam penelitian ini, berbagai hipotesis dapat diajukan terhadap aspek-aspek kebahasaan dengan desain konfirmatori. Jadi sebagai penelitian eksploratori, artikel ini merupakan studi deskriptif kualitatif yang tujuannya adalah untuk meningkatkan pemahaman dan pendalaman dari proses dan bahan ajar buku berfungsi sebagai sumber dari segala informasi, harus sesuai dengan kebutuhan yaitu penyesuaian terhadap tuntutan kurikulum yang berlaku. Dalam penelitian ketepatan konsep materi subjek pada buku teks Biologi bilingual SMP Kelas IX semester 2 pada topik pewarisan sifat terbitan Erlangga, untuk menentukan kriteria pedagogi dari mudah diajarkan berdasarkan indikator silabus Biologi Kurikulum Tingkat Satuan Pendidikan.

Menurut Haryati (2008) bahwa standar kompetensi merupakan batas dan arah kemampuan yang perlu dimiliki dan dapat dilakukan siswa setelah mengikuti proses pembelajaran dalam suatu mata ajar tertentu. Kandungan materi pada kompetensi dasar lebih 
Quagga: Jurnal Pendidikan dan Biologi

Volume 11, Nomor 2, Juli 2019

sempit dan konkrit dari pada standar kompetensi. Adapun kata kerja yang digunakan adalah kata kerja operasional diantaranya menghitung, mengidentifikasi, membedakan, menafsirkan, menganalisis, menerapkan, merangkum, dan lain-lain. Dari kompetensi dasar ini kemudian diuraikan menjadi beberapa indikator. Indikator merupakan karakteristik, ciri-ciri, perbuatan atau respon yang ditunjukkan dan dilakukan oleh siswa yang berkaitan dengan kompetensi dasar. Dalam hal ini buku teks menjadi sumber informasi utama bagi peserta didik untuk merangsang cara berfikir dan belajar siswa secara mandiri sehingga pembelajaran tidak lagi sepenuhnya bertumpu pada seorang pendidik (guru). Dengan demikian, dalam penyusunannya buku teks hendaknya dibuat sebaik dan sejelas mungkin untuk menunjang proses pembelajaran karena persiapan materi pelajaran yang baik dengan media pengajaran yang mendukung akan menjadikan pengajaran lebih efektif dan terarah.

\section{METODOLOGI PENELITIAN}

Terdapat beberapa instrumen yang digunakan dalam penelitian yaitu silabus biologi KTSP, buku teks Biologi bilingual SMP Kelas IX, ketepatan konsep materi subjek buku teks biologi disertai dengan model Penyajian motif berupa outline. Langkah-langkah yang dilakukan dalam penelitian ini membuat perangkat penelitian berupa sampel bacaan dan table ketepatan konsep dengan menyajikan motif suatu materi berdasarkan memadai, kurang atribut, dan tidak dituntut dalam indikator untuk mengetahui kelengkapan uraian materi pada buku teks. Herlanti, Y. (2014), Metode pengumpulan data yang digunakan oleh peneliti melalui observasi dengan menganalisis secara
p-ISSN 1907-3089, e-ISSN2651-5869

https://journal.uniku.ac.id/index.php/quagga

langsung buku teks tersebut dalam sebuah ketepatan konsep materi subjek untuk mengetahui penyajian motif suatu materi. Data tersebut dianalisis dengan cara diorganisir unit struktur makro dan struktur mikro dari suatu materi subjek.

\section{HASIL DAN PEMBAHASAN}

Kompleksitas kedalaman suatu materi diketahui pada proposisi dengan tingkat abstraksi tinggi dinyatakan dengan $\mathrm{P}$ (proposisi makro) dan proposisi dengan tingkat abstraksi rendah dilambangkan dengan S (proposisi mikro). Hal tersebut terrdapat pada uraian buku teks yang disajikan dalam model penyajian motif.

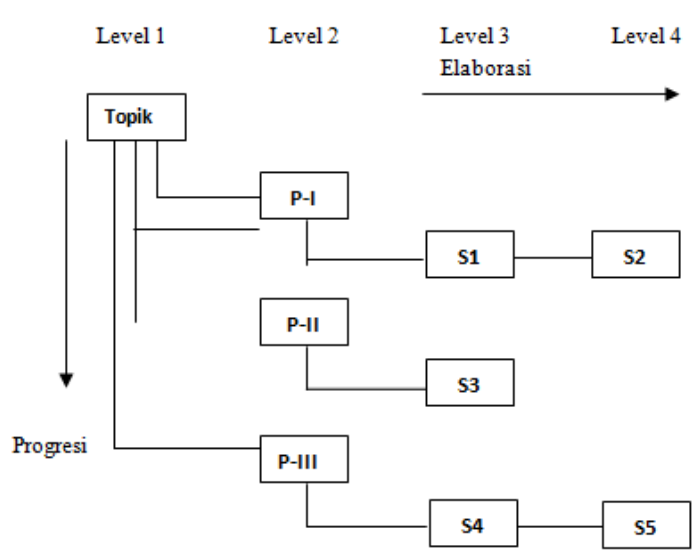

Ketepatan konsep buku teks menguraikan eksplanasi penyajian motif dan analisis tingkat ketepatan konsep, dilakukan untuk mengetahui tingkat kedalaman struktur pengetahuan materi subjek buku teks Biologi bilingual SMP kelas IX terbitan Erlangga tahun terbit 2012 Ariningrum, TR. (2013). 
Gambar 1.Proposisi Global Pewarisan Sifat (Characteristic Inheritance)

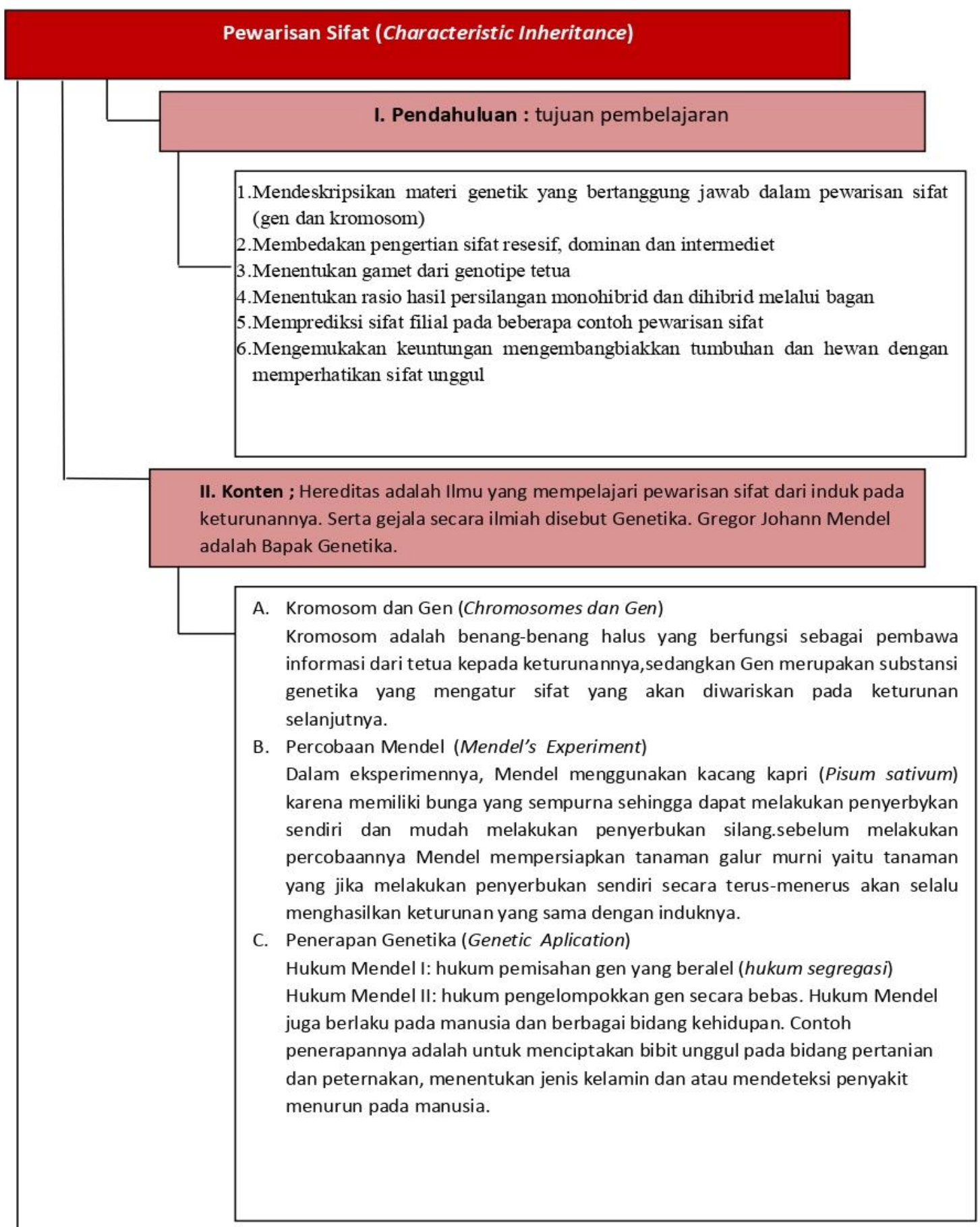

III. Penutup : untuk mempermudah dalam mempelajari sub konsep pewarisan sifat harus memahami terlebih dahulu arti dari kata kunci (key terms) yang terdapat pada konsep tersebut

$\begin{array}{ll}\text { 1.Alel } & \text { 7. Genotipe } \\ \text { 2. Kromosom } & \text { 8. Fenotipe } \\ \text { 3. Dihibrid } & \text { 9. Intermediet } \\ \text { 4. Monohibrid } & \text { 10. Resesif } \\ \text { 5.Dominan } & \text { 11. Hereditas } \\ \text { 6.Gen } & \end{array}$


Tabel 1. Rekapitulasi Hasil Analisis Tingkat Ketepatan Konsep Buku Teks Biologi Bilingual SMP Kelas IX Semester 2 pada materi Pewarisan Sifat Terbitan Erlangga Tahun Terbit 2012

\begin{tabular}{|c|c|c|c|c|c|}
\hline \multirow[b]{2}{*}{ No. } & \multirow[b]{2}{*}{ Bab } & \multirow[b]{2}{*}{ Label konsep } & \multicolumn{3}{|c|}{ Ketepatan Konsep } \\
\hline & & & Memadai & $\begin{array}{l}\text { Kurang } \\
\text { Atribut }\end{array}$ & $\begin{array}{c}\text { Tidak } \\
\text { dituntut } \\
\text { dalam } \\
\text { indikator }\end{array}$ \\
\hline 1 & \multirow{11}{*}{ 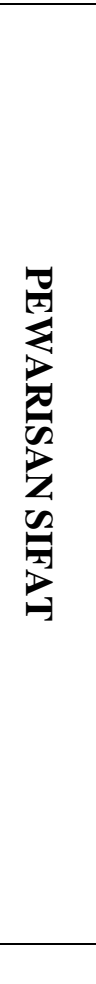 } & $\begin{array}{l}\text { Kromosom dan Gen } \\
\text { (Chromosomes and Genes) }\end{array}$ & $\sqrt{ }$ & & \\
\hline 2 & & $\begin{array}{l}\text { Kromosom diploid dan haploid } \\
\text { (Diploid and haploid } \\
\text { chromosomes) }\end{array}$ & & & $\sqrt{ }$ \\
\hline 3 & & $\begin{array}{l}\text { Genotipe dan fenotipe } \\
\text { (Genotype and phenotype) }\end{array}$ & $\sqrt{ }$ & & \\
\hline 4 & & $\begin{array}{l}\text { Dominan, resesif dan } \\
\text { intermediet } \\
\text { recessive, and intermediate) }\end{array}$ & $\sqrt{ }$ & & \\
\hline 5 & & $\begin{array}{l}\text { Simbol dan istilah dalam } \\
\text { persilangan ( Symbol and } \\
\text { terminology in crossing) }\end{array}$ & & & $\sqrt{ }$ \\
\hline 6 & & $\begin{array}{l}\text { Percobaan Mendel (Mendel's } \\
\text { Experiment) }\end{array}$ & $\sqrt{ }$ & & \\
\hline 7 & & Monohibrid (Monohybrid) & $\sqrt{ }$ & & \\
\hline 8 & & Dihibrid (Dihybrid) & $\sqrt{ }$ & & \\
\hline 9 & & $\begin{array}{l}\text { Hukum-hukum } \\
\text { (Mendel's laws) }\end{array}$ & $\sqrt{ }$ & & \\
\hline 10 & & $\begin{array}{ll}\text { Penerapan } & \text { genetika } \\
\text { (Genetic Applications) } & \end{array}$ & & $\sqrt{ }$ & \\
\hline & & Jumlah & 7 & 1 & 2 \\
\hline
\end{tabular}

Ketepatan konsep pada materi pewarisan sifat, masih ditemukan konsep kurangnya atribut kritis. Berikut ini adalah hasil persentase ketepatan konsep materi yang terkandung di dalam buku.
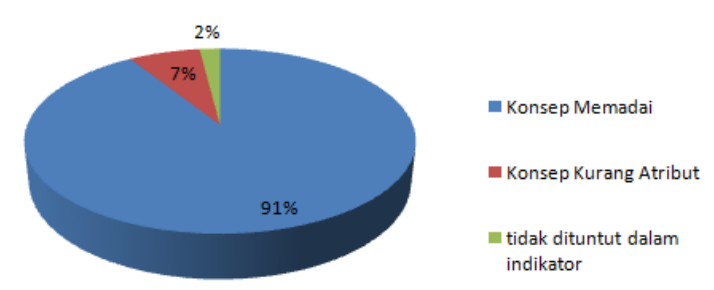

Gambar 2. Ketepatan konsep

Hal ini menyajikan kelebihan tersendiri bagi buku teks tersebut karena materi yang tidak terakomodasi dalam indikator silabus dikategorikan sebagai materi pengayaan .

\section{Pembahasan}

Ketepatan konsep adalah studi tentang pengkajian fungsi fragmatik bahasa yang dilakukan secara sistematis terhadap suatu kalimat, teks dan konteks, sehingga makna yang terkandung dalam kalimat dapat ditafsirkan . Sebagai konten wacana, komponen materisubyek berfungsi sebagai rujukan nilai kebenaran. Istilah konten di sini mengambil pengertian umum, yaitu, materi (bukan dalam konteks struktur pengetahuan) untuk berlangsungnya kegiatan belajar-mengajar. Peranan sentral materi-subyek diwujudkan sebagai komponen yang menjadi rujukan dalam proses mengkonstruksi pengetahuan. Pengajar merujuknya untuk maksud mengorganisasikan dan merepresentasikan materi-subyek agar mudah dijangkau oleh pembelajar, merujuk dan mendalaminya untuk mengembangkan strategi belajarnya agar pemahamannya meningkat. Pemetaan tugas kedua komponen PBM di atas dapat didasarkan pada kriteria mudah dengan demikian dapat diarahkan kepada deskripsi dari fungsi-fungsi ini dalam bentuk eksplanasi pedagogi. 
Menurut Leatemia, M. (2014), gambaran diatas terbatas pada komponen-komponen PBM, belum mengungkapkan antar-hubungannya secara lebih terfokus pada logika internal PBM, yaitu, tugas membangun pengetahuan. Bagian ini membahas mengembangkan antar-hubungan tersebut menurut fungsinya masing-masing, tetapi tidak menyertakan pembahasan mengenai upaya bersama membangun pengetahuan, karena merupakan substansi dari Membangun Bersama Pengetahuan. Jika dilihat bahwa fungsi utama pengajar adalah menyampaikan eksplanasi, pertanyaan yang kemudian muncul adalah bagaimana bentuk eksplanasi tersebut. Dapat dipastikan bahwa bentuk tersebut tidak memadai jika disamakan dengan bentuk eksplanasi ilmuwan, karena, target eksplanasi di dalam PBM adalah pembelajar yang status keilmuannya adalah pemula.

Susilowati, S. M. E. (2012) menyatakan bahwa dalam kegiatan belajar, antar hubungan dari setiap komponen perlu dipetakan berdasarkan peranan sentral materi-subyek, karena tugas pengajar adalah mengalih bentuk materi-subyek (yang belum menampilkan struktur tertentu) menjadi struktur makro. Upaya ini adalah upaya transformasi ilmu yang disepakati bersama oleh para pakar menjadi suatu representasi tertentu yang mengutamakan pemahaman pembelajar untuk memfasilitasi proses membangun bersama pengetahuan. Dengan demikian perlu dibedakan antara eksplanasi ilmiah, di satu pihak, dan eksplanasi pedagogi, di lain pihak agar kemungkinan timbulnya kerancuan antara pandangan pakar ilmuwan dan pakar pendidikan dapat dihindari walaupun baru pada tingkat konseptual.

Pengorganisasian pedagogi dapat dilihat dari hasil ketepatan konsep yang secara komprehensif menampilkan model representasi mengajar yang merupakan hasil abstraksi dari pengorganisasian unit-unit wacana yakni proposisi. Proposisi merupakan unit dasar informasi dalam sistem pemrosesan informasi. Proposisi dapat disamakan dengan gagasan yang selalu terdiri atas dua unsur, yaitu hubungan dan argumen. Dalam proposisi, hubungan berperan sebagai penjelas argumen, sehingga hubungan bisa berupa kata kerja, kata sifat, atau kata keterangan. Meskipun hubungan mempunyai makna yang lebih sempit dari argumen, tetapi hubungan dapat membatasi argument. Salah satu tugas utama dalam ketepatan konsep adalah mengorganisasi unit terkecil proposisi mikro (pengukuhan yang mewakili struktur permukaan teks) menjadi unit yang lebih besar, proposisi makro yang secara berulang-ulang dapat digabung menjadi proposisi makro pada berbagai tingkat abstraksi yang akhirnya menjadi proposisi global. Deskripsi struktur global tersebut berfungsi untuk memudahkan penelusuran bagaimana proses membangun pengetahuan dalam pengorganisasisn konten, substantif dan sintaktikal.

Menurut Aminah, S. (2008) dalam ketepatan konsep yang ditemukan adalah konsep memadai, kurangnya atribut, dan tidak adanya konsep dalam indikator. Penilaian ketepatan konsep memadai, artinya terdapat ketepatan atau kesamaan konsep dalam buku teks Biologi bilingual SMP kelas IX semester 2 pada materi pewarisan sifat dengan analisis konsep ditinjau dari atribut kritisnya. Untuk konsep kurang atribut, yaitu terdapat pada konsep yang memiliki atribut kritis tidak lengkap pada analisis konsep. Sementara konsep yang tidak dituntut dalam indikator, yaitu konsep yang terdapat di buku teks Biologi bilingual tetapi tidak ada di indikator, biasanya masuk pada materi pengayaan. ditemukan 10 konsep dengan tingkat ketepatan konsep, yaitu 7 konsep memadai diantaranya kromosom dan gen, genotipe dan fenotipe, dominan, resesif dan, percobaan Mendel, monohibrid, dihibrid dan hukum-hukum Mendel. Selanjutnya untuk definisi konsep kurangnya atribut, terdapat 1 konsep kurang atribut yaitu penerapan genetika, dan terdapat 2 konsep tidak dituntut dalam indikator yaitu kromosom diploid dan haploid, serta simbol dan istilah dalam persilangan.

Ramli, m. (2012), sistematika penilaian buku tidak luput dari standar penilaian yang dianjurkan Badan Nasional Standar Pendidikan. Untuk mengukur kedalaman dan kompleksitas materi dilakukan dengan cara mengalisis ketepatan konsep materi subjek menurut teori Nelson Siregar. Pada teori ini, Siregar menjelaskan tentang aspek materi subjek dengan menerapkan ketepatan konsep terhadap proses belajar mengajar. Adapun keungulan dalam menggunakan teori ini adalah mampu mengkonstruksi keterkaitan hubungan antara pelajar, pembelajar, dan materi subjek (bahan ajar). Hal tersebut dapat terlihat ketika analisis dari ketepatan konsep materi subjek mampu menghasilkan penyajian motif terlihat pengorganisasian struktur materi makro dan mikro yang melibatkan berbagai proposisi 
Quagga: Jurnal Pendidikan dan Biologi

Volume 11, Nomor 2, Juli 2019

(gagasan). Penyajian wacana materi subjek buku teks pada suatu ilmu perlu sesuai dengan kurikulum yang ditetapkan. Apabila hal tersebut telah terbentuk, maka kualitas buku dapat diketahui setelah menganalisis kompleksitas dari suatu materi. Ketepatan ini akan berdampak positif pada tujuan kurikulum, yaitu aspek pengetahuan, sikap dan ketrampilan siswa yang dapat menunjukkan suatu perubahan terhadap perilaku siswa. Aspek tersebut merupakan hal yang terkandung di dalam tujuan Pendidikan Nasional.

\section{SIMPULAN}

Ketepatan konsep buku teks Biologi bilingual SMP kelas IX semester 2 materi pewarisan sifat ditemukan 10 konsep yang dipaparkan oleh penulis (tabel 4.2). Berdasarkan standar analisis konsep terdapat 91\% konsep memadai, $7 \%$ konsep kurangnya atribut, dan $2 \%$ konsep yang tidak dituntut dalam indikator. Artinya konsep-konsep yang ditemukan di dalam buku teks dikatakan sangat baik serta buku teks tersebut dapat digunakan dalam proses pembelajaran sebagai bahan ajar dan berfungsi sebagai buku teks bilingual yang tepat.

\section{REFERENSI}

Aminah, S. (2008). Ketepatan konsep pesan moral dalam novel Laskar Pelangi karya Andrea Hirata.

Ariningrum, TR. 2013. Analisis Literasi Ilmiah Buku Teks Pelajaran Biologi SMA. Skripsi, Jurusan Biologi FMIPA Universitas Negeri Semarang.

Haryati. 2008. Model Dan Teknik Penilaian Pada Tingkat Satuan Pendidikan. Jakarta: Gaung Persada Press.

Herlanti, Y. (2014). Tanya jawab seputar penelitian pendidikan sains.

Leatemia, M. (2014). Pengaruh Strategi SQ4R Tipe Bantuan Multimedia vs Buku Teks, Pengetahuan Awal, Gaya Belajar Kolb terhadap Hasil Belajar Bahasa Inggris Teknik. Jurnal Pendidikan Humaniora (JPH), 1(4), 426-436.
p-ISSN 1907-3089, e-ISSN2651-5869

https://journal.uniku.ac.id/index.php/quagga

Ramli, m. (2012). Analisis substansi pendidikan multikultural sains di buku pelajaran biologi untuk sma. In prosiding seminar biologi (vol. 9, no. 1).

Susilowati, S. M. E. (2012). Analisis Buku Ajar Ipa Biologi Yang Banyak Digunakan Di SMP Negeri Kabupaten Jepara. Journal of Biology Education, 1(2). 